\title{
RGEC, Sustainability Reporting, and Financial Performance: A Study in Listed Banks in IDX 2013-2017
}

\section{Tri Gunarsih ${ }^{1}$, Setiyono ${ }^{1}$, Fran Sayekti ${ }^{1}$, and Tamas Novak ${ }^{2}$}

${ }^{1}$ Universitas Teknologi Yogyakarta, Siliwangi Street, North Ring Road, Sleman, D.I.Y., Indonesia

${ }^{2}$ Budapest Business School, H-1051 Budapest, Marko Street 29-31, Hungary

\section{Abstract}

This study aims to analyze Risk Profile, Good Corporate Governance, Earning, and Capital (RGEC), Sustainability Reporting (SR) and financial performance (ROE and TQ) of the listed banks in the IDX. This research implements correlation and regression analysis. Base on data samples of 12 banks in 2013-2017, the results of this study show that GCG and RGEC positively correlated to performance (ROE and TQ), but there is no correlation between SR and performance. The regression analysis shows that risk profile (LDR), GCG, and Earning / rentability (ROA) are statistically significant influence

Corresponding Author:

Tri Gunarsih

trigunarsih@uty.ac.id

Received: 5 August 2019

Accepted: 14 August 2019

Published: 18 August 2019

Publishing services provided by

Knowledge E

(c) Tri Gunarsih et al. This article

is distributed under the terms of

the Creative Commons.

Attribution License, which

permits unrestricted use and redistribution provided that the original author and source are credited.

Selection and Peer-review under the responsibility of the FGIC2019 Conference Committee.

\section{G OPEN ACCESS} ROE but only NPL and GCG that influence TQ while SR is not significant, both to ROE and TQ. These findings support the arguments that the better the RGEC, the higher the financial performance. Subject to data limitation of SR, this study could not give empirical evidence that the better the SR, the higher the firm performance.

Keywords: RGEC, sustainability reporting, performance, bank.

\section{Introduction}

The RGEC are four indicators in the healthy of commercial bank base on risk approach as in Bank Indonesia Regulation (PBI) Number 13/1/PBI/2011 issued by Bank Indonesia (the Central Bank of Republic Indonesia). Bank health must be maintained and improved so that public trust in the Bank can be maintained. Also, the Bank's Soundness used as a means of evaluating the conditions and problems faced by the Bank and determining follow-up to overcome the Bank's weaknesses or challenges, either in the form of Bank corrective action or supervisory action by Bank Indonesia. Then, maintaining the RGEC will keep public trust and improve performance. Base on the PBI, Banks are needed to conduct assessments by themselves (self-assessment) base on the Bank Soundness Levels. The self-assessment of the Bank's Health Level is carried out at least every semester for the positions at the end of June and December. The average of RGEC in 2013-2017 for 12 bank samples is as Figure 1. The score was modified, from 1 for the 
highest number to 5 for the highest number. The average RGEC fluctuate from 3.8 to 4.8. This data will attract questions whether the more elevated the RGEC, the higher the performance.

\section{RGEC}

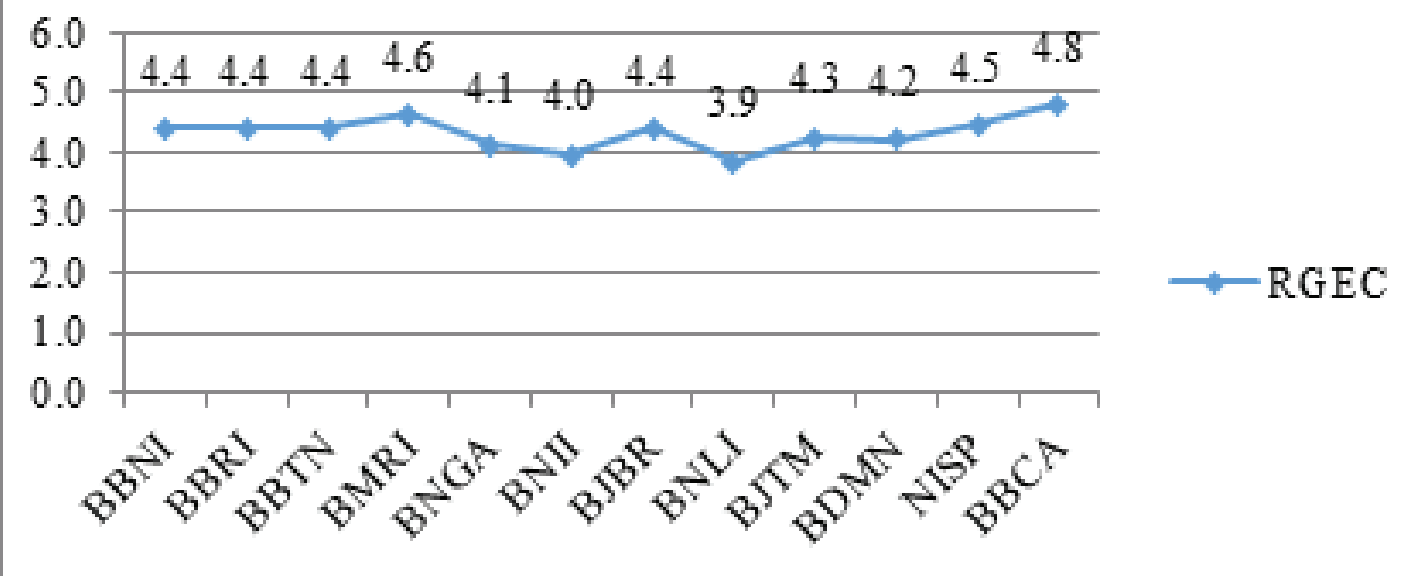

Figure 1: RGEC Average Sample Firms.

According to GRI (Global Reporting Initiative, 2016), "An SR is a report published by a company or organization about the economic, environmental and social impacts caused by its everyday activities. An SR also presents the organization's values and governance model and demonstrates the link between its strategy and its commitment to a sustainable global economy". In Indonesia, SR has a voluntary character. However, SR will be mandatory in the future, as the Financial Service Authority (FSA) regulation number 51/POJK.03/2017 Date July $18^{\text {th }}, 2018$.

$\mathrm{SR}$ is currently not binding yet, so not all of the banks issued SR in Indonesia. Figure 2 shows the average of SR and the average of SR indicators (economic, environmental, and social) of sample firms. The score range is between 1 to 5, 1 for Not Applied, 2 for Bit Applied, 3 for Partially Applied, 4 for Almost Applied, and 5 for Fully Applied. The economic and social trend is positive while the environment and SR average fluctuate. This number also raises the question of whether the higher the SR, the higher the performance.

Some studies in banking industry and financial institutions support the argument that the more efficient risk management system, the higher the performance (Wanjohi, 2017; Marozva, 2015; Singh, 2015; Maudos and Guevara, 2004; Tabari et al., 2013; Hene and Amoh, 2016; Tarraf and Majeske, 2008) and the higher score of SR the better the performance (McIntyre, 2016; Uwuigbe, 2018; Nwobu, 2015; Buallay, 2018). Studies in bank risk management and performance are varied, both in proxies and analysis results 


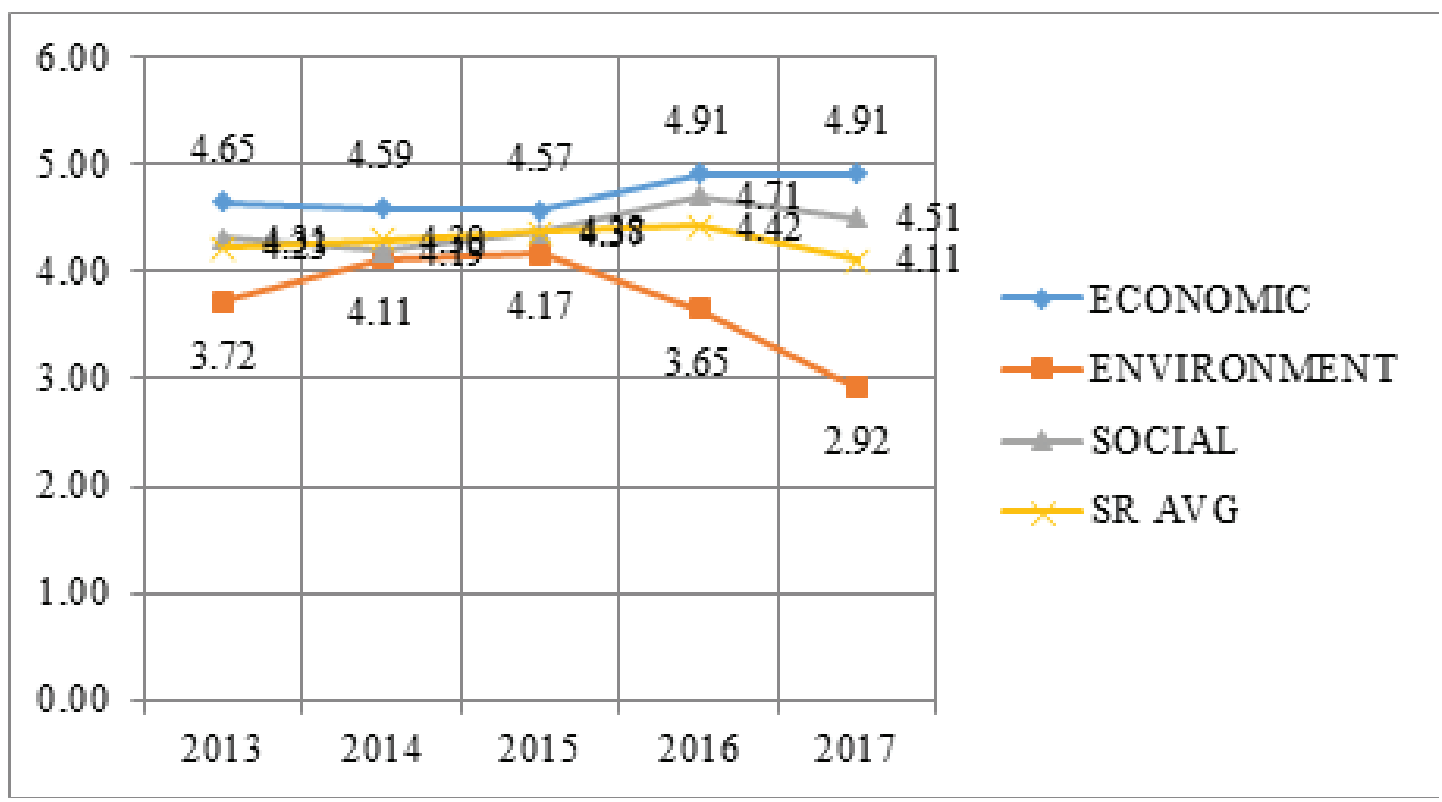

Figure 2: SR Score Average of Sample Firms.

as well. Marozva (2015) analyzed the net interest margin and funding liquidity risk and found a significant negative relationship between both variables. Other studies measure different proxy as a risk indicator, for example, credit risk (Singh, 2015) and overall risk index (Hene and Amoh, 2016) in their study in the Ghana Stock Exchange (GSE).

Some studies in SR and performance construct SR index base on the content analysis in sustainability reports (Uwuigbe, 2018 and Nwobu, 2015), but McIntyre (2016) build SR base on primary data, comprised of 64 multiple-choice questions and several openended questions targeted at those who have experience with SR. The proposition of the legitimacy theory confirmed by Uwuigbe (2018). The study found that there was a significant negative influence between the market price per share on SR. Also, the study found there was a significant favorable impact of SR on the revenue generation. Nwobu (2015) found that there is a small positive correlation between SR index to profit after tax (PAT) as performance measurement, saw a slight positive correlation SR index and PAT and also found a low positive relationship between SR index and shareholders fund.

Some studies in risk, SR, and performance show the mixed construct and results, then there is still an area to reexamine those three variables. This research aims to analyze the RGEC, SR, and banks' financial performance in the IDX. This study implements the correlation to investigate the relationship between those three variables and regression to analyze a causality between RGEC and financial performance and SR with business performance. 


\section{Literature Review}

\subsection{Global Reporting Initiative (GRI)}

The GRI Standards are designed to enhance the worldwide comparability and quality of information on these impacts, thereby enabling greater transparency and accountability of organizations. These Standards are intended to be used by organizations to report about their effects on the economy, the environment, and society.

The GRI Standards consists of two main parts; they are universal standards and topicspecific standards. The global standards include GRI 101 (Foundation), GRI 102 (General Disclosure) and GRI 103 (Management Approach). The topic-specific rules consist of GRI 200 (Economic topics), GRI 300 (Environmental issues) and GRI 400 (Social issues).

\subsection{RGEC}

The definition of risk is anything that can create hindrances in the way of achievement of specific objectives. The risk base on a particular situation could be either internal factors or external factors. One of the tools of credit risk management is risk rating model (Kanchu and Kumar, 2013).

In Indonesia, in the framework of banks' risk management and performance, Bank Indonesia (The Central Bank of Republic Indonesia) issued Bank Indonesia Regulation (PBI) Number 13/1/PBI/2011, concerning The Healthy of Commercial Banks base on risk approach (risk-based bank rating). The method consists of 4 indicators, RGEC. The Bank's Soundness Rating using a Risk-based Bank Rating based on a comprehensive analysis of performance, risk profile, problems encountered, and prospects for the Bank's development, as follows: (a) The risk profile; (b) Good Corporate Governance (GCG); (c) Profitability; and (d) Capital. Before the issuance of RGEC, Commercial Banks in Indonesia should implement Regulation Number 6/10/PBI/2004 as Bank Soundness Indicators.

\subsection{Risk and Financial Performance studies in Banking}

Studies in risk and financial performance varied in term of proxies and results (Singh, 2015; Hene and Amoh, 2016; Marozva, 2015 and Tabari et al., 2013). Marozva (2015) and Tabari et al. (2013) analyze risk in a context of liquidity and found different results 
in their study. Marozva (2015) found that the relationship between net interest margin and funding liquidity risk is negative.

Tabari et al. (2013) found that the improvement of the performance of banks was caused by the bank's variables of micro and macro, while the weakening of the performance of the banks created by credit risk and liquidity risk. Base on the literature reviews, the first hypothesis of this study is the lower the bank's risk, the higher the financial performance.

\subsection{SR and Financial Performance Studies in Bankings}

Most studies in SR adopt SR base on GRI guidelines and use of content analysis and coded to obtain the sustainability disclosure index (Uwuigbe, 2018; Kishore and Prakash, 2019; Nwobu, 2015; Buallay, 2018; Kumar and Prakash, 2019). However, other studies, McIntyre (2016) developed SR index base on 64 multiple-choice questions and several open-ended questions targeted at those who have experience with SR. Kumar and Prakash (2019) analyze the banks operating in India, in the extent of SR. They developed a sustainability indicator based on the content analysis technique derived from the literature review, GRI G4 guidelines, and the National Voluntary Guidelines responsible business conduct. The sustainability indicator implemented in analyzing the SR, corporate social responsibility report, business responsibility report, an annual report of the banks. The study concluded that the banks in India are much slower in adopting SR practices. Wanjohi et al. (2017) analyzed the commercial banks in Kenya and found that there was a positive correlation between financial risk management practices to financial performance. Nwobu (2015) found that SR index and PAT are positively correlated. Based on the literature review, the second hypothesis of this research is, the better the SR index, the higher the financial performance.

\section{Research Method}

\subsection{Sample}

Samples in this research are banks, listed in the IDX in 2013-2017, selected using purposive sampling, based on the criteria as follows.

i. Listed in the IDX in 2013-2017.

ii. The SR, RGEC, and financial data are available during 2013- 2017. 


\subsection{Measurement of Variables}

\subsubsection{Dependent Variable}

Tobin's $Q$ and ROE are the dependent variables in this study.

\subsubsection{Independent variables}

The independent variables consist of RGEC and SR as follows.

\section{RGEC}

The RGEC in this study comprises of 4 indicators, Risk Profile, Good Corporate Governance, Earning, and Capital. The four indicators based on the bank's self-assessment in the annual report. The signs then rank from the very healthy, healthy, quite healthy, less healthy, and unhealthy. In this research, the health level is modified as 5,4,3,2,1 from the best to the worst. Earning/rentability proxied by Return on Asset (ROA) and Capital proxied by Capital Adequacy Ratio (CAR).

\section{SR Index}

$\mathrm{SR}$ is the average of the three dimensions of SR index, comprised of economic, environmental, and social. The index developed base on GRI guidelines and the use of content analysis and coded to obtain the sustainability disclosure index. SR each aspect computed using the following formula:

i. Economic dimension

$$
S R D I_{e c}=\frac{n}{k}
$$

Where:

$S R D I_{e c}=S R$ Disclosure Index economic dimension

$\mathrm{n}=$ total number of levels disclosure in economic dimension disclosed by the company

$\mathrm{k}=$ total item of economic dimension published by the company

ii. Environment dimension

$$
S R D I_{\text {env }}=\frac{n}{k}
$$


Where:

$S R D I_{e n v}=S R$ Disclosure Index environment dimension

$\mathrm{n}=$ total number of level disclosure in environment dimension disclosed by the company

$\mathrm{k}=$ total item of environment dimension disclosed by the company

iii. Social dimension

$$
S R D I_{s o c}=\frac{n}{k}
$$

Where:

$S R D I_{s o c}=S R$ Disclosure Index social dimension

$\mathrm{N}=$ total number of level disclosure in social dimension disclosed by the company

$\mathrm{k}=$ total item of social dimension published by the company

iv. SR average

$$
S R=\frac{S R D I e c+S R D I e n c+S R D I s o c}{3}
$$

Where:

$S R=S R$ average

\subsection{Regression Model}

Two regression models, model (5) and (6) are implemented to test the two hypotheses. The first hypothesis, the lower the bank's risk, the higher the financial performance will be supported if the regression coefficient of $X_{2}, X_{3}, X_{4}, X_{5}$, and $X_{6}$ are statistically significant. The second hypothesis of this study, the better the SR index, the higher the financial performance will be supported if the regression coefficient of $X_{1}$ is statistically significant. The two models are as follows.

$$
\begin{aligned}
& \mathrm{ROE}=\lambda_{0}+\lambda_{1} \mathrm{~A}_{1}+\lambda_{2} \mathrm{~A}_{2}+\lambda_{3} \mathrm{~A}_{3}+\lambda_{4} \mathrm{~A}_{4}+\lambda_{5} \mathrm{~A}_{5}+\lambda_{6} \mathrm{~A}_{6}+\eta \\
& \mathrm{TQ}=\lambda_{0}+\lambda_{1} \mathrm{~A}_{1}+\lambda_{2} \mathrm{~A}_{2}+\lambda_{3} \mathrm{~A}_{3}+\lambda_{4} \mathrm{~A}_{4}+\lambda_{5} \mathrm{~A}_{5}+\lambda_{6} \mathrm{~A}_{6}+\eta
\end{aligned}
$$

Where:

$$
\begin{aligned}
& \mathrm{ROE}=\text { Return on Equity } \\
& \mathrm{TQ}=\text { Tobin's } \mathrm{Q} \\
& \mathrm{A}_{1}=\mathrm{SR} \text { average (SR) } \\
& \mathrm{A}_{2}=\text { Non-Performing Loan (NPL) }
\end{aligned}
$$


$A_{3}=$ Loan to Deposit Ratio (LDR)

$A_{4}=$ Good Corporate Governance (GGC)

$A_{5}=$ Return on Assets (ROA)

$A_{6}=$ Capital Adequacy Ratio (CAR)

\section{Results and Discussion}

\subsection{Data Descriptives}

Table 1 shows the average number of SR, RGEC (the average number of RGEC indicators), Tobin's $Q(T Q)$, and Return on Equity (ROE). The highest average SR index in 2013-2017 is BNII (4.66). The highest average RGEC is BBCA (4.8). The highest number of $T Q$ is BBRI (2.17), and the highest number of ROE is BBRI $(0.20)$.

TABLE 1: Average number each sample in 2013-2017.

\begin{tabular}{|l|c|c|c|c|}
\hline SAMPLE CODE & SR & RGEC & TQ & ROE \\
\hline BBNI & 4.61 & 4.40 & 1.04 & 0.13 \\
\hline BBRI & 4.55 & 4.40 & 2.17 & 0.20 \\
\hline BBTN & 3.58 & 4.40 & 0.98 & 0.10 \\
\hline BMRI & 4.32 & 4.64 & 1.08 & 0.12 \\
\hline BNGA & 3.94 & 4.12 & 0.96 & 0.07 \\
\hline BNII & 4.66 & 3.96 & 1.00 & 0.07 \\
\hline BJBR & 3.77 & 4.40 & 1.03 & 0.12 \\
\hline BNLI & 4.51 & 3.85 & 0.97 & -0.02 \\
\hline BJTM & 4.29 & 4.25 & 1.01 & 0.13 \\
\hline BDMN & 4.62 & 4.20 & 1.04 & 0.08 \\
\hline NISP & 4.31 & 4.47 & 0.99 & 0.08 \\
\hline BBCA & 4.78 & 4.80 & 1.42 & 0.18 \\
\hline
\end{tabular}

Table 2 shows the descriptive statistic. The total number of observation is 51 . Subject to data limitation, in the regression models, the SR is not divided into three dimensions, but only the SR average. The mean number of ROE is 0.1051 . This number suggests that the average net income divided by equity is $10.51 \%$. The mean number of TQ is 1.1405. This number indicates that the market value of the samples is higher than the book value. The NPL, LDR, GCG, ROA, CAR, RGEC, and SR variables are ordinal data, and the highest (best) number is 5 . The closer the mean of those variables to 5 , the better the variables. 
TABLE 2: Descriptive Statistics.

ROE
TQ
NPL
LDR
GCG
ROA
CAR
RGEC
SR
Valid N (listwise)

\begin{tabular}{|c|c|}
\hline N & Min. \\
\hline 51 & -0.34 \\
\hline 51 & 0.92 \\
\hline 51 & 4 \\
\hline 51 & 3 \\
\hline 51 & 3 \\
\hline 51 & 1 \\
\hline 51 & 3 \\
\hline 51 & 3.40 \\
\hline 51 & 2.08 \\
\hline 51 & \\
\hline
\end{tabular}

\begin{tabular}{|c|}
\hline Max. \\
\hline 0.27 \\
\hline 2.65 \\
\hline 5 \\
\hline 4 \\
\hline 5 \\
\hline 5 \\
\hline 5 \\
\hline 4.80 \\
\hline 5.00 \\
\hline
\end{tabular}

\begin{tabular}{|c|c|}
\hline Mean & Std. Devi. \\
\hline 0.1051 & 0.08452 \\
\hline 1.1405 & 0.37000 \\
\hline 4.76 & 0.428 \\
\hline 3.14 & 0.348 \\
\hline 4.20 & 0.491 \\
\hline 4.53 & 0.966 \\
\hline 4.90 & 0.413 \\
\hline 4.31 & 0.321 \\
\hline 4.29 & 0.745 \\
\hline
\end{tabular}

Table 3 describes the correlation between RGEC, SR, TQ, and ROE. The GCG and RGEC are positively significance to both financial performance, ROE, and TQ. This number suggests that the better the GCG and RGEC, the higher the business performance. SR variable not correlated with business performance. The possible explanations are the data limitation and the voluntary of SR.

TABLE 3: Correlation.

\begin{tabular}{l|c|c|c|c|c|c} 
& ROE & TQ & NPL & GCG & ROA & CAR \\
\hline TQ & $0.496^{* * *}$ & - & - & - & - & - \\
\hline LDR & - & - & - & - & - & - \\
\hline GCG & $0.519^{* * *}$ & $0.448^{* * *}$ & $0.319^{* *}$ & - & - & - \\
ROA & $0.683^{* * *}$ & - & - & $0.367^{* * *}$ & - & - \\
CAR & & - & - & - & $0.333^{* *}$ & - \\
RGEC & $0.615^{* * *}$ & $0.26^{*}$ & $0.418^{* * *}$ & $0.678^{* * *}$ & $0.822^{* * *}$ & $0.533^{* * *}$ \\
SR & - & - & - & - & - & - \\
Note: -: there is no correlation. & ${ }^{* * *}$ sig. at $\alpha 1 \%,{ }^{* *}$ sig. at $\alpha 5 \%{ }^{*}$ sig. at $\alpha 10 \%$
\end{tabular}

\subsection{Regression Analysis}

The regression results are as in table 4 . The $F$ value of both models (model 5 and 6 ) are statistically significant at $\alpha 1 \%$. The R square and Adjust. $\mathrm{R}^{2}$ of model 5 is higher than model 6 . This result suggests that the model with the dependent variable book value is better than market value.

Three independent variables of RGEC are significant in model 5 , but unfortunately SR variable is not statistically significant. The LDR variable is statistically significant at $\alpha 10 \%$ with the $t$ value -1.882 . The negative sign of the coefficient $(-0.049)$ suggests that the lower the LDR, the higher the ROE. The decreasing number of LDR will increase ROE. 
The GCG variable is statistically significant at $\alpha 1 \%$ with the $t$ value 3.115. The positive sign of the coefficient (0.065) suggests that the better the GCG mechanism implementation, the higher the ROE. The ROA variable is statistically significant at $\alpha 1 \%$ with the $t$ value 5.136. The positive sign of the coefficient $(0.052)$ suggests that the higher the ROA as the one indicators of RGEC, the higher the ROE.

TABLE 4: Regression Analysis.

\begin{tabular}{|c|c|c|c|c|c|c|}
\hline & \multicolumn{3}{|c|}{ ROE (Model 5) } & \multicolumn{3}{|c|}{ TQ (Model 6) } \\
\hline & Coef. & $\mathrm{t}$ & sig & Coef & $\mathrm{t}$ & sig \\
\hline (Constant) & -0.162 & -0.996 & 0.325 & 0.703 & 0.741 & 0.463 \\
\hline SR & 0.009 & 0.752 & 0.456 & 0.046 & 0.669 & 0.507 \\
\hline NPL & -0.016 & -0.744 & 0.461 & -0.328 & $-2.608^{* *}$ & 0.012 \\
\hline LDR & -0.049 & $-1.882^{*}$ & 0.067 & -0.180 & -1.190 & 0.240 \\
\hline GCG & 0.065 & $3.115^{* * *}$ & 0.003 & 0.449 & $3.720^{* * *}$ & 0.001 \\
\hline ROA & 0.052 & $5.136^{* * *}$ & 0.000 & 0.012 & 0.195 & 0.846 \\
\hline CAR & -0.011 & -0.489 & 0.627 & 0.088 & 0.692 & 0.493 \\
\hline$F$ & & $10.758^{* * *}$ & 0.000 & & $3.472^{* * *}$ & 0.007 \\
\hline R Square & & 0.595 & & & 0.321 & \\
\hline Adjusted R Square & & 0.539 & & & 0.229 & \\
\hline
\end{tabular}

Two independent variables are significant in model 6 , but as in model 5 , SR is not statistically significant. The NPL variable is statistically significant at $\alpha 5 \%$ with the t value -2.608. The negative sign of the coefficient $(-2.608)$ suggests that the lower the LDR, the higher the TQ, then to increase the TQ, the banks should decrease the NPL. The GCG variable is statistically significant at $\alpha 1 \%$ with the $t$ value 3.720 . The positive sign of the coefficient (0.449) suggests that the better the GCG mechanism implementation, the higher the TQ. This model suggests that the TQ will increase in the NPL is decrease, and the GCG is increasing.

The GCG variable is consistently statistically significant at $\alpha 1 \%$ in both models, ROE as a proxy of book value and TQ as a proxy of market value. The positive sign of the coefficients suggests that the financial performance in term of book value and market value will increase if the GCG implementation increase.

Some variables of RGEC as indicators of risk base rating are statistically significant in both models (model 7 and 8). These suggest that RGEC influence financial performance. The result of this study support the argument that the more efficient of risk management system, the higher the performance as in Wanjohi (2017), Marozva (2015), Singh (2015), Maudos and Guevara (2004), Tabari et al. (2013), Hene and Amoh (2016), and Tarraf and Majeske (2008). 
The SR variable is not statistically significant in both models (model 7 and 8). This study could not give empirical evidence to support the argument that the higher the score of SR the higher the performance as in Mclntyre (2016), Uwuigbe (2018), Nwobu (2015), Buallay (2018).

\section{Conclusion and Implications}

The objective of this research is to analyze the RGEC (risk bank rating), SR, and financial performance in banking industry listed in the IDX. This study implements the correlation to investigate the relationship between those three variables and regression to analyze the causality between RGEC and the financial performance and SR with the financial performance, base on data samples of 12 banks in 2013-2017.

The correlation results show that GCG and RGEC positively correlated with performance (ROE and TQ). This correlation suggests that the better the GCG implementation and the higher the RGEC score will improve the financial performance. This study also shows that there is no correlation between SR and performance.

The regression analysis shows that risk profile (LDR), GCG, and Earning / rentability (ROA) are statistically significant influence ROE but only risk profile (NPL) and GCG that influence TQ while SR is not significant, both to ROE and TQ. These suggest that the better the RGEC will increase the financial performance, and to increase the business performance, the banks should improve the rank of RGEC. Subject to data limitation of $\mathrm{SR}$, this study could not give empirical evidence that the better the SR, the higher the firm performance.

Further study may employ more data sample. In the future, when SR is mandatory, there will be more data to be analyzed, so that the indicator of SR may employ the three dimension of SR disclosure index (the economic aspect, the environment dimension, and the social dimension. Subject to data limitation, this study only implements SR as the average of those three variables.

\section{Funding}

This article is a part of the research outcome that is funded by the Min. of Res., Tech. and the Higher Ed. Republic Indonesia as contract no 111/SP2H/LT/DRPM/2019. 


\section{References}

[1] Bank of Indonesia. (2011). Bank Indonesia Regulation (PBI) Number 13/1/PBI/2011.

[2] Buallay, Amina. (2018). Is sustainability reporting (ESG) associated with performance? Evidence from the European banking sector. Management of Environmental Quality: An International Journal, https://doi.org/10.1108/MEQ-12-2017-0149

[3] Financial Sevices Authority. (2017). Regulation of Financial Services Authority No. 51/POJK.03/2017 on Application of Sustainable Finance to Financial Services Institution, Issuer, and Publicly Listed Companies.

[4] GRI. (2016). GRI 101: Foundation. Global Sustainability Standards Board (GSSB), Amsterdam.

[5] Hene, Eric Dei Ofosu and Peter Amoh. (2016). Risk Management and Performance of Listed Banks in Ghana. European Journal of Business Science and Technology, 2(2), 107-121.

[6] Kanchu, Thirupathi and M. Manoj Kumar. (2013). Risk Management in the Banking sector, an Empirical Study. International Journal of Marketing, Financial Services \& Management Research, 2 (2), 145 -153.

[7] Kumar, Kishore and Ajai Prakash. (2019). Examination of sustainability reporting practices in the Indian banking sector. Asian Journal of Sustainability and Social Responsibility, 4 (2), 1-16. https://doi.org/10.1186/s41180-018-0022-2.

[8] Marozva, Godfrey. (2015). Liquidity And Bank Performance. International Business \& Economics Research Journal, 14 (30), 453-461.

[9] Maudos, J., and J. Guevara. (2004). Factors Explaining the Interest Margin in the Banking Sectors of the European Union. Journal of Banking and Finance, 28, 22592281.

[10] McIntyre, Barbara Turley, Ashleigh Marchl, and Brenda Stasuik. (2016). Sustainability Reporting in Canada's Financial Institutions. Journal of Co-operative Accounting and Reporting, 4 (1): 35-58.

[11] Nwobu, Obiamaka. (2015). The Relationship between Corporate Sustainability Reporting and Profitability and Shareholders Fund in Nigerian Banks. Journal of Accounting and Management, 5 (3), 1-12.

[12] Singh, Asha. (2015). Effect of Credit Risk Management on Private and Public Sector Banks in India. International Journal of Academic Research in Business and Social Sciences 5 (1),: 2222-6990. 
[13] Tabari, Naser Ail Yadollahzadeh, Mohammad Ahmadi, and Ma'someh Emami. (2013). The Effect of Liquidity Risk on the Performance of Commercial Banks. International Research Journal of Applied and Basic Sciences, 4 (6), 1624-1631.

[14] Tarraf, Hussein and Karl Majeske. (2008). Impact of risk-taking on bank financial performance during 2008 financial crisis. www.aabri.com/NO2013Manuscripts/ N013024.pdf

[15] Uwuigbe, Uwalomwa, Obarakpo Teddy, Olubukola Ranti Uwuigbe, Ozordi Emmanuel, Osariemen Asiriuwa, Gbenedio Akpevwenoghene Eyitomi, and Oluwagbemi Simeon Taiwo. (2018). Sustainability Reporting and Firm Performance: a Bi-Directional Approach. Academy of Strategic Management Journal, 17 (3),1-16.

[16] Wanjohi, Stephen Muthii, Joel Githinji Wanjohi, and James Muchiri Ndambiri. (2017). The Effect of Financial Risk Management on the Financial Performance of Commercial Banks in Kenya. International Journal of Finance and Banking Research, 3 (5), 70-81. 